\title{
PENGKAJIAN UJI ADAPTASI VARIETAS PADI UNGGUL BARU TAPANULI SELATAN SUMATERA UTARA
}

DI KABUPATEN

\author{
Delima Napitupulu ${ }^{1^{*}}$ \\ ${ }^{1}$ Balai Pengkajian Teknologi Pertanian Sumatera Utara Medan (20143) \\ *Corresponding author : d5na70@gmail.com
}

\begin{abstract}
Study of six high yielding varieties of rice adaptation performed on wetland rice fields in the North of Sumatera.The activities focus on location in Pintu Padang I village. The objective is to implement mentoring activities rice technology through the test and open-field VUB adaptation to increase rice production. The team have been mentoring technology of SL-PTTRice in West Tapanuli Regency, as has been done in 2013. Mentoring of the application of technological innovation with approaches Integrated Crop Management (PTT). The test of adaptation to six varieties (Inpari 3, Inpari 10, Inpari 14, Inpari 15, Inpari 16 dan Mekongga). Through this activity, carried rice varieties test an acre in one location. The technologies presented are: new varieties, cropping patterns legowo 4:1, fertilizing, pest control, etc.. The test of adaptation to six varieties, the highest result was Mekongga (8,2 t/ha), Inpari $14(8,1$ t/ha) and Inpari $15(8,1 \mathrm{t} / \mathrm{ha})$., so these varieties is very potential to be developed of the farmer and stakeholders.
\end{abstract}

Key Word : Adaptation, Variety, Paddy, West Tapanuli Regency

\begin{abstract}
ABSTRAK
Kegiatan uji varietas unggul baru padi dilakukan Sumatera Utara. Tujuan penelitian ini adalah untuk melihat varietas unggul baru tanaman padi di Desa Pintu Padang, Kecamatan Batang Angkola, Kabupaten Tapanuli Selatan, dengan menggunakan 6 varietas unggul padi yaitu : Inpari 3, Inpari 10, Inpari 14, Inpari 15, Inpari 16 dan Mekongga didukung oleh komponen-kompenen dalam pelaksanaan SLPTT. Melalui kegiatan ini, dilaksanakan uji varietas padi pada satu lokasi seluas 1 ha. Teknologi yang disampaikan berupa varietas baru, Pola tanam legowo 4:1, pemupukan, pengendalian hama dll. Inovasi teknologi yang digunakan adalah pendekatan Pengelolaan Tanaman Terpadu (PTT) padi sawah dan perlakuan petani sebagai kontrol. Uji VUB dengan menggunakan PTT memberikan hasil tertinggi pada Mekongga, diikuti oleh Inpari 14 dan Inpari 15, masing -masing 8,2 t/ha, 8,1 t/ha dan 7,9 t/ha. Perlakuan petani menunjukkan hasil tertinggi pada varietas Mekongga dan Inpari 3, masing-masing 7 t/ha dan 6,5 t/ha. Kegiatan uji VUB ini disenangi oleh petani dan perangkat daerah karena mampu tumbuh pada kondisi musim kemarau dan irigasi teknis yang rusak. Untuk itu varietas tersebut sangat potensial untuk dikembangkan petani dan pengguna lainnya.
\end{abstract}

Kata Kunci : Adaptasi, Varietas, Padi, Tapanuli Selatan

\section{PENDAHULUAN}

Kabupaten Tapanuli Selatan merupakan kabupaten yang mempunyai potensi untuk produksi padi sawah di Sumatera Utara yang berada pada dataran tinggi. Pada tahun 2011 luas panen mencapai 29.325 ha dengan produksi sebesar 146.181 ton (BPS, 2012). Bila dilihat dari data produksi per satuan luas adalah 4,98 ton/ha, hampir sama dengan 
rata-rata Sumatera Utara sebesar 4,89 ton/ha.

Masalah yang selalu dihadapi petani dalam budidaya tanaman padi adalah: terabaikannya penggunaan bahan organik, pemakaian pupuk kimia dan pestisida kimia yang tinggi, penggunaan benih lokal / benih turun temurun, penggunaan bibit umur tua, jumlah bibit 5-10 bibit per lubang, jarak tanam tidak teratur, menggenangi sawah terus menerus. Jika dibiarkan terus-menerus, maka akan terjadi pelandaian produktivitas padi.

Varietas unggul baru padi masih belum berkembang karena penyebaran dan tingkat penggunaannya sampai ke petani masih rendah sehingga menyebabkan rendahnya produksi dan produktivitas hasil. Kurangnya sosialisasi varietas unggul baru, tidak tersedia benih/sulit mendapatkan benih, varietas yang diterima tidak sesuai dengan selera petani dan agroklimat setempat, sering menjadi penyebab kurang berkembangnya varietas unggul baru .

Sehubungan dengan itu dalam rangka peningkatan produksi dan produktivitas melalui penggantian varietas, perlu ditingkatkan penggunaan varietas unggul baru dengan menggantikan varietas unggul lama. Untuk itu perlu adanya penelitian uji varietas untuk tanaman padi (Situmorang, et al., 2008). Menurut Hasanuddin, (2005), bahwa sumbangan peningkatan produktivitas Varietas Unggul Baru (VUB) terhadap produksi nasional cukup besar yaitu sekitar $56 \%$.

Penerapan teknologi sesuai SLPTT melalui penggunaan input produksi yang efisien menurut spesifik lokasi mampu meningkatkan produktivitas yang tinggi pada tanaman padi. Varietas lokal mempengaruhi kondisi cuaca, keadaan tata air dan jenis tanah mengakibatkan hasil yang beragam. Penggunaan varietas unggul dupayakan mampu menghasilkan dan menyebarkan varietas padi unggul baru yang lebih beragam sehingga kerapuhan genetik tidak segera muncul.
Dalam rangka mendukung program Kementerian Pertanian menuju swasembada pangan dan peningkatan kesejahteraan petani, penerapan teknologi yang berwawasan lingkungan dan berkelanjutan perlu dilakukan. Teknologi tersebut dikenal dengan nama teknologi Pengelolaan Tanaman Terpadu (PTT). Dalam kegiatan PTT terdapat lima komponen dasar yang harus dilaksanakan antara lain, memakai varietas unggul, menggunakan benih bermutu, pemberian bahan organik seperti kompos, pupuk kandang atau pupuk Pupuk Organik Granular (POG), pengaturan populasi tanaman secara optimum seperti sistem tanam legowo (4:1), dan pemberian pupuk berdasarkan kebutuhan tanaman melalui analisis contoh tanah (Zaini et al, 2009).

Hapsah (2005) menyatakan bahwa peningkatan produktivitas padi dapat diupayakan melalui penggunaan varietas unggul baru. Menurut Setyorini et al (2006) untuk menentukan ketepatan dalam pemberian pupuk padi sawah dapat dilakukan melalui penggunaan alat Perangkat Uji Tanah Sawah (PUTS), atas kerjasama Badan Litbang Pertanian dengan IRRI dosis pupuk padi sawah juga dapat diketahui melalui internet dengan mendownload Pengelolaan Hara Spesifik Lokasi (PHSL) atau http://webapps.irri.org/nm/id.

Tujuan pengkajian adalah untuk melihat adaptasi varietas unggul baru di Kabupaten Tapanuli Selatan melalui penerapan teknologi PTT.

\section{BAHAN DAN METODE}

Kegiatan dilaksanakan dari bulan April hingga September 2013 di Desa Pintu Padang, Kecamatan Batang Angkola, Kabupaten Tapanuli Selatan, Sumatera Utara. Penelitian menggunakan Rancangan Acak Kelompok dengan dan diulang sebanyak tiga kali. Perlakuan terdiri dari varietas Inpari 3, 10, 14, 15, 16 dan Mekongga. Masing-masing varietas ditanam secara legowo (4:1) pada lahan 
seluas 1 ha. Sebelum tanam lahan diolah sempurna dan diratakan, selanjutnya ditaburkan pupuk kandang sapi sebanyak 2 t/ha. Pemberian pupuk anorganik berdasarkan hasil analisis status hara tanah dengan PUTS dan pemberian pupuk susulan berdasarkan Bagan Warna Daun (BWD), pengendalian OPT secara terpadu, dan panen tepat waktu dan dirontok menggunakan tresher.

Pupuk dasar diberikan berdasarkan rekomendasi PUTS yaitu pupuk Urea sebanyak $100 \mathrm{~kg} / \mathrm{ha}$ pada umur 7 HST (Hari Setelah Tanam). Selanjutnya pupuk Urea diberikan pada 25 dan 35 HST masing-masing sebanyak $75 \mathrm{~kg} / \mathrm{ha}$, pemberian SP-36 sebesar $150 \mathrm{~kg} / \mathrm{ha}$ dan pemberian $\mathrm{KCl}$ sebesar $50 \mathrm{~kg} / \mathrm{ha}$. Untuk pencegahan terhadap serangan hama dan penyakit, pada saat tanam diberikan Insektisida Curater dan untuk pengendalian hama keong dengan pemberian Saponin. Pada pertumbuhan selanjutnya tanaman disemprot dengan Insektisida dan Fungisida lainnya.

Peubah yang diamati meliputi keragaan tanaman (jumlah anakan pada umur 30 HST, tinggi tanaman maksimum), komponen hasil (jumlah anakan produktif, gabah hampa per malai, bobot seribu butir dan hasil per hektar (gabah kering panen), serta tingkat serangan hama dan penyakit. Panen dilakukan sesuai umur varietas yang diuji, ditandai gabah telah menguning atau matang lebih dari $85 \%$. Selama kegiatan berjalan dilakukan pengamatan yang diulang sebanyak 5 kali untuk masingmasing varietas terhadap pertumbuhan tanaman dan komponen hasil. Sedangkan terhadap hasil gabah dilakukan pengamatan pada petak ubinan 4x5 m dengan 3 kali ulangan. Selanjutnya data pengamatan diolah secara statistik dan uji lanjut menurut Duncant pada taraf 5\% (Gomez et all, 1995).

\section{HASIL DAN PEMBAHASAN}

\section{Pertumbuhan Tanaman}

Jumlah anakan varietas Inpari 14, 15, 16 dan Mekongga tidak memperlihatkan perbedaan yang nyata tetapi masing-masing varietas memiliki nilai yang lebih tinggi dibanding varietas Inpari 3 dan Inpari 10. Jumlah anakan terbanyak pada umur 30 HST terlihat pada varietas Mekongga dan tanaman tertinggi pada saat panen juga ditunjukkan oleh varietas Inpari 10 (Tabel 1).

Tabel 1. Jumlah anakan (30 HST) dan tinggi tanaman $(\mathrm{cm})$ saat panen beberapa varietas padi sawah terhadap penerapan teknologi PTT di Desa Pintu Padang, Kecamatan Batang Angkola, Kabupaten Tapanuli Selatan

\begin{tabular}{cccc}
\hline No & $\begin{array}{c}\text { Varietas } \\
\text { Padi }\end{array}$ & $\begin{array}{c}\text { Jumlah Anakan } \\
(30 \mathrm{HST})\end{array}$ & $\begin{array}{c}\text { Tinggi Tanaman } \\
\text { saat panen }(\mathrm{cm})\end{array}$ \\
\hline 1 & Inpari 3 & $16.2 \mathrm{c}$ & $95.83 \mathrm{c}$ \\
2 & Inpari 10 & $18.6 \mathrm{~b}$ & $112.67 \mathrm{a}$ \\
3 & Inpari 14 & $20.1 \mathrm{a}$ & $104.33 \mathrm{~b}$ \\
4 & Inpari 15 & $18.9 \mathrm{ab}$ & $107.33 \mathrm{ab}$ \\
5 & Inpari 16 & $18.9 \mathrm{ab}$ & $102.83 \mathrm{~b}$ \\
6 & Mekongga & $20.5 \mathrm{a}$ & $106.33 \mathrm{ab}$ \\
\hline & Rata-rata & 18.87 & 104.89 \\
\hline & CV $(\%)$ & 7.99 & 5.31 \\
\hline
\end{tabular}

Keterangan : Angka pada kolom yang diikuti oleh huruf yang sama tidak berbeda nyata pada taraf uji 5\% DMRT

Penampilan pertumbuhan yang berbeda dari beberapa varietas yang diuji disebabkan oleh sifat genetik dari tanaman itu sendiri (Suprihatno, et al., 2009). Keragaman genetis antar populasi akan menghasilkan ekspresi genetis yang 
beragam (Sunarti, et al, 2006). Pertumbuhan masing-masing varietas diduga tidak dari pengaruh pemberian pupuk adalah sangat kecil karena pemberian pupuk diberikan dengan dosis yang sama untuk enam varietas yang diuji.

Pada saat panen varietas Inpari 10, Inpari 15, Mekongga, Inpari 14 dan Inpari 16 berturut-turut nyata menunjukkan tinggi tanaman tertinggi dibandingkan varietas Inpari 3. Menurut Sudarsono dan Makarim (2008) peningkatan hasil padi sawah pada suatu tempat perlu dilakukan melalui uji adaptasi varietas unggul baru. Varietas dengan penampilan pertumbuhan yang baik pada lokasi tersebut tentu diharapkan akan memberikan hasil yang baik pula. Disamping itu penerapan sistem tanam jajar legowo juga dapat mempengaruhi terhadap pertumbuhan tanaman dan hasil padi sawah. Adanya ruang kosong diantara baris tanaman pencahayaan akan lebih optimal diambil oleh tanaman sehingga pertumbuhan tanaman akan lebih baik.

\section{Komponen Hasil}

Komponen hasil dan hasil yang diberikan terhadap masing-masing varietas yang diuji nyata memberikan pengaruh yang berbeda (Tabel 2). Dari komponen hasil, jumlah malai terbanyak per rumpun diperoleh pada varietas Mekongga. Hal ini sejalan juga dengan jumlah gabah isi dan bobot 1000 butir paling tinggi terdapat pada varietas Mekongga.

Tabel 2. Rataan jumlah malai, panjang malai (cm), jumlah gabah isi per malai (butir) dan bobot 1000 butir (gram) dari beberapa varietas unggul baru padi sawah terhadap penerapan teknologi PTT di Desa Pintu Padang, Kecamatan Batang Angkola Kabupaten Tapanuli Selatan

\begin{tabular}{|c|c|c|c|c|c|c|}
\hline $\begin{array}{l}\text { Varietas } \\
\text { yang diuji }\end{array}$ & $\begin{array}{l}\text { Jumlah } \\
\text { malai } \\
\text { (batang) }\end{array}$ & & $\begin{array}{l}\text { Panjang } \\
\text { malai }(\mathrm{cm})\end{array}$ & $\begin{array}{l}\text { Jumlah gabah } \\
\text { hampa per } \\
\text { malai (butir) }\end{array}$ & $\begin{array}{l}\text { Jumlah gabah isi } \\
\text { per malai } \\
\text { (butir) }\end{array}$ & $\begin{array}{l}\text { Bobot } 1000 \\
\text { butir }(\mathrm{g})\end{array}$ \\
\hline Inpari. 3 & 10.9 & $\mathrm{c}$ & $105.2 \mathrm{c}$ & $15.6 \mathrm{a}$ & $96.5 \mathrm{~d}$ & $24.50 \quad b$ \\
\hline Inpari.10 & 11.9 & $\mathrm{c}$ & $110.1 \quad b$ & $16.6 \mathrm{a}$ & $109.6 \mathrm{c}$ & $27.67 \mathrm{ab}$ \\
\hline Inpari.14 & 15.4 & $\mathrm{a}$ & $120.5 \mathrm{a}$ & $15.2 \mathrm{a}$ & $124.4 \quad \mathrm{a}$ & $27.50 \mathrm{ab}$ \\
\hline Inpari.15 & 14.2 & $a b$ & $117.8 \mathrm{ab}$ & $16.1 \mathrm{a}$ & $120.9 \mathrm{~b}$ & $25.83 \mathrm{~b}$ \\
\hline Inpari.16 & 13.0 & $\mathrm{~b}$ & $116.9 \mathrm{ab}$ & $16.4 \mathrm{a}$ & $116.7 \mathrm{bc}$ & $24.83 \mathrm{~b}$ \\
\hline Mekongga & 15.5 & $\mathrm{a}$ & $119.1 \mathrm{a}$ & $15.9 \mathrm{a}$ & $126.9 \mathrm{a}$ & $28.50 \quad \mathrm{a}$ \\
\hline Rata-rata & 13.48 & & 114.93 & 15.97 & 115.83 & 26.47 \\
\hline CV (\%) & 13.94 & & 5.20 & 3.23 & 9.73 & 6.23 \\
\hline
\end{tabular}

Keterangan : Angka pada kolom yang diikuti oleh huruf yang sama tidak berbeda nyata pada taraf uji 5\% DMRT

Komponen hasil terbanyak terhadap gabah hampa terlihat diberikan oleh varietas Inpari 10 tetapi tidak ada perbedaan yang nyata diantara ke enam varietas uggul tersebut. Gabah hampa terjadi karena kurangnya distribusi assimilat ke biji. Penyebab lainnya diduga kurangnya hara mikro yang diberikan ke tanaman. Hara mikro memiliki peranan penting dalam pembentukan biji (Utama dan Widodo, 2009).

Jumlah gabah isi per malai lebih tinggi pada varietas Mekongga dan Inpari
14. Hal ini diduga berhubungan dengan panjang malai. Semakin panjang malai, peluang untuk membentuk gabah isi juga akan semakin besar. Tabel 2 menunjukkan kedua varietas ini memberikan hasil yang lebih tinggi dibanding dengan varietas lainnya.

Berat 1000 butir tertinggi terdapat pada varietas Mekongga. Hal ini sejalan juga dengan jumlah gabah isi tertinggi dihasilkan oleh varietas Mekongga. berat gabah kering panen juga lebih rendah pada Inpari 3 dibanding dengan varietas lainnya. 
Tabel 3. Jumlah anakan produktif (butir) dan hasil gabah kering panen (GKP) yang diperoleh dari beberapa varietas unggul baru padi sawah terhadap penerapan teknologi PTT di Desa Pintu Padang, Kecamatan Batang Angkola Kabupaten Tapanuli Selatan

\begin{tabular}{|c|c|c|c|}
\hline No. & $\begin{array}{l}\text { Varietas } \\
\text { yang diuji }\end{array}$ & $\begin{array}{c}\text { Jumlah Anakan } \\
\text { produktif } \\
\text { (batang) }\end{array}$ & $\begin{array}{l}\text { Hasil } \\
\text { GKP } \\
(\mathrm{t} / \mathrm{ha})\end{array}$ \\
\hline 1 & Inpari. 3 & $13 \mathrm{~b}$ & $6.40 \mathrm{~d}$ \\
\hline 2 & Inpari.10 & $13.5 \mathrm{~b}$ & $6.90 \mathrm{C}$ \\
\hline 3 & Inpari.14 & $15 \mathrm{a}$ & $8.10 \mathrm{~A}$ \\
\hline 4 & Inpari.15 & $14 \mathrm{~b}$ & $7.90 \mathrm{ab}$ \\
\hline 5 & Inpari.16 & $13.5 \mathrm{ab}$ & $7.50 \quad \mathrm{~B}$ \\
\hline \multirow[t]{3}{*}{6} & Mekongga & $16.5 \mathrm{a}$ & $8.20 \quad \mathrm{~A}$ \\
\hline & Rata-rata & 14.25 & 7.50 \\
\hline & $\mathrm{CV}(\%)$ & 9.08 & 9.58 \\
\hline
\end{tabular}

Keterangan : Angka pada kolom yang diikuti oleh huruf yang sama tidak berbeda nyata pada taraf uji $5 \%$ DMRT

Jumlah anakan produktif dan hasil gabah kering panen menunjukkan korelasi positif pada varietas Mekongga dibanding dengan varietas lain. Hal ini sejalan juga dengan bobot 1000 butir yang tinggi, jumlah anakan produktif yang tinggi dan gabah isi tertinggi pada varietas Mekongga. Hal ini didukung oleh Swasti et al (2008) yang menyatakan bahwa bobot 1000 butir bergantung pada ukuran gabah, bentuk gabah dan waktu pemanenan. Tetapi dengan jumlah anakan yang banyak pula maka total jumlah gabah yang dihasilkan lebih banyak sehingga akan berpengaruh pada total produksi padi yang dihasilkan.

Hasil padi rata-rata di Kabupaten Tapanuli Selatan hanya 4 t/ha dan dilokasi pengkajian rata-rata 5 t/ha sebelum adanya uji varietas dengan menggunakan benih varietas lokal dan varietas Ciherang. Hasil gabah kering panen tertinggi setelah uji varietas terdapat pada varietas Mekongga. Hal ini didukung oleh Atman (2005) yang menyatakan salah satu faktor yang mempengaruhi peningkatan hasil gabah padi adalah meningkatnya nilai komponen pertumbuhan dan komponen hasil tanaman, antara lain: jumlah anakan produktif, panjang malai, jumlah gabah per malai, dan persentase gabah bernas. Artinya, makin banyak jumlah anakan maksimum maka jumlah anakan produktif meningkat sehingga hasil gabah juga meningkat. Selanjutnya, makin banyak jumlah gabah per malai maka hasil gabah juga semakin bertambah.

Hasil terrendah $(6.40$ t/ha $)$ diperlihatkan oleh varietas Inpari 3 dan selanjutnya disusul oleh varietas Inpari 10 dengan hasil yaitu 6.90 t/ha. Kedua varietas Inpari ini rata-rata memperlihatkan adaptasi yang kurang baik disbanding varietas lainnya. Sedangkan terhadap keempat varietas lainnya memberikan hasil diatas $6 \mathrm{t} / \mathrm{ha}$. Kurang baiknya adaptasi varietas Inpari 3 dan 10 pada lokasi pengkajian diduga banyak faktor yang mempengaruhinya seperti suhu tinggi/panas, musim kemarau berkepanjangan, saluran air irigasi rusak, penyinaran matahari serta tingkat kesuburan tanah yag masih rendah saat dilakukan uji dengan perangkat PUTS. Pendapat yang sama juga dikemukakan oleh Dobermann dan Fairthurts (2000) bahwa hasil padi sawah sangat dipengaruhi oleh faktor iklim, tingkat kesubuan lahan dan varietas yang adaptif pada daerah penanaman. Penanaman varietas yang sesuai dan pemberian pupuk yang tepat serta proses penyinaran yang optimal sehingga tanaman akan memberikan hasil 
yang baik. Kaihatu dan Marietje (2011) juga menyatakan potensi hasil dari suatu varietas hanya dapat dicapai jika ditanam pada kondisi pertumbuhan yang sesuai dengan varietas tersebut. Perbedaan cuaca, keadaan tata air dan jenis tanah mengakibatkan hasil yang beragam. Penggunaan varietas unggul dalam upaya peningkatan produksi, memegang peranan penting.

Hama yang sering menyerang adalah keong karena sering hujan tetapi setiap serangan mulai muncul, petani langsung memberantas dengan menggunakan insektisida hama keong seperti buldox.

Melalui hasil penelitian ini, varietas padi sawah yang cocok dikembangkan di Kabupaten Tapanuli Selatan dapat disimpulkan petani antusias menanam Inpari 14 atau mekongga. Varietas mekongga merupakan varietas yang sudah lama disukai petani karena umurnya singkat, tanaman tegak, bentuk padinya ramping serta teksturnya pulen. Berdasarkan uraian diatas, varietas unggul Mekongga yang diuji menunjukkan penampilan agronomi dan produksi yang lebih baik.

\section{SIMPULAN DAN SARAN}

\section{Simpulan}

Padi varietas Mekongga memberikan adaptasi yang cukup baik dengan hasil gabah kering panen sebanyak $8.2 \mathrm{t} / \mathrm{ha}$. Varietas Mekongga menunjukkan penampilan agronomi yang lebih baik dibanding varietas lainnya. Selanjutnya disusul oleh varietas Inpari 14 dan 15 dengan hasil 8.10 dan 7.90 t/ha sehingga sesuai untuk dikembangkan pada sentra produksi padi di Kecamatan Batang Angkola, Kabupaten Tapanuli Selatan.

\section{Saran}

Varietas Mekongga dan Inpari 14 dapat disarankan untuk dikembangkan khususnya di Desa Pintu Padang,
Kecamatan Batang Angkola Kabupaten Tapanuli Selatan.

\section{DAFTAR PUSTAKA}

BPS Kabupaten Tapanuli Selatan. 2012. Kabupaten Tapanuli Selatan Dalam Angka. Badan Pusat StatistikKabupaten Tapanuli Selatan.

Dobermann, A., and T. Fairthurts. 2000. Rice Nutrient Disorders and Nutrient Management. International Rice Research Institute (IRRI). Los Banos. Philipinnes.192p.

Gomez, K.A. \& A.A. Gomez. 1995. Prosedur Statistik untuk Pertanian (edisi ke-2). Sjamsuddin, E., J.S. Barharsjah (Penerjemah). Jakarta: Penerbit Universitas Indonesia (UIPress). Terjemahan dari: Statistical Procedures for Agricultural Research. 698 hal.

Hapsah, M.D. 2005. Potensi, Peluang, dan Strategi Pencapaian Swasembada Beras dan Kemandirian Pangan Nasional. Hal. 55-70. Dalam B. Suprihatno et al. (Ed.) Inovasi Teknologi Padi Menuju Swasembada Beras Berkelanjutan. Buku Satu. Balitbangtan, Badan Litbang Pertanian.

Hasanudin, A. 2002. Inovasi Teknologi Peningkatan Produksi Tanaman Pangan di Indonesia. Bahan Pelatihan bagi Tenaga Pendamping P3T di Bogor dan Sukamandi, 7-12 Maret 2002.

Kaihatu, S. S. dan Marietje, P. 2011. Adaptasi Beberapa Varietas Unggul Baru Padi Sawah di Morokai. Jurnal Agrivigor 11(2):178-184. 2011. ISSN 14122286.

Situmorang S, Rajihan, Rumonton, 2008. Sistem Produksi Benih Padi Bersertifikat. UPT. BPSD IV. Sumatera Utara. 
Sunarti, S., Nuning, A.S., Marsum, M.D. 2006. Keragaan Hasil 24 Jagung Bersari Bebas Pada Lahan Masam Pasang Surut di Kabupaten Kapuas Kalimatan Tengah. Widyariset. Vol. 9(3): 203-208.

Suprihatno, B., Aan A. D., Satoto, Baihaki, Suprihanto, Agus S., Dewi I., Moh. Yamin S., Hasil S., 2009. Deskripsi Varietas Padi. Balai Besar Penelitian Tanaman Padi.

Swasti,E.,A.B. Syarief, Irfan Suliansyah, Nurwanita Ekasari Putri. 2008. Potensi Varietas Lokal Sumatera Barat sebagai Sumber Genetik dalam Pemuliaan Tanaman Padi. Prosiding Simposium Penelitian Tanaman Pangan V.Buku 2. Pusat Penelitian dan Pengembangan Tanaman Pangan, Bogor, 28 29Agustus 2007 : 409 - 413 .

Utama, M.Z.H dan Widodo, H. 2009. Pengujian Empat Varietas Padi Unggul Pada Sawah Gambut BukaanBaru di Kabupaten Padang Pariaman. Jurnal Akta Agrosia Vo. 12 No. 1. Hal. 56-61.

Zaini, Z., Sarlan Abdurrahman, Nyoman Widiarta, Putu Wardana, Diah Setyorini, S. Kartaatmadja, Moh. Yamin, 2009. Pedoman Umum PTP Padi Sawah. Badan Litbang Pertanian. 